\title{
Teknik penyajian presentasi ilmiah yang efektif dengan menggunakan media elektronik
}

\author{
Elizabeth Mailoa \\ Bagian Prostodonsia \\ Fakultas Kedokteran Gigi Universitas Hasanuddin \\ Makassar, Indonesia
}

\begin{abstract}
The digital era has transformed the manner in which scientific material is presented to dental professional. With recent technological advances, speakers presenting information have greater options to deliver their materials. Most notably, speakers are able to use media to assist and enhance presentations. Recent technology of presentations with software such as PowerPoint has becoming popular lately, because this software has many advantages, such as the ability to incorporate graphics, text and sound in a multimedia files. An effective presentation is when your audience can easily grasp the ideas you are trying to get across. In scientific presentations engaging and clear visuals complement the speaker role of translating and communicating information. Scientific presentation with projecting images and test stimulates audience attention and retention. The purpose of this article is to provide key points on in focus in the delivery of presentation, and to maximize its effectiveness by using the benefit of electronic digital media.
\end{abstract}

Key word: effectively scientific presentation, electronic presentation media.

\begin{abstract}
ABSTRAK
Era digital telah mengubah cara presentasi ilmiah di kalangan para profesional, termasuk profesi dokter gigi. Seiring dengan perkembangan teknologi yang lebih canggih, hal ini menguntungkan bagi pembicara untuk memilih cara menyampaikan materinya dalam pertemuan ilmiah. Lebih khusus lagi, pembicara dapat menggunakan media elektronik untuk membantu meningkatkan materi presentasinya. Perkembangan teknologi presentasi seperti program PowerPoint merupakan perangkat lunak yang paling populer dalam pembuatan materi presentasi oleh karena memiliki banyak keuntungan, terutama kemampuan memadukan gambar, teks dan suara. Presentasi yang efektif yaitu bilamana hadirin dapat mencerna dengan mudah informasi yang disampaikan. Penyajian visual yang menarik dan jelas akan melengkapi peranan pembicara dalam menyampaikan dan mengkomunikasikan materi yang dibawakan. Presentasi yang dilengkapi dengan tampilan gambar dan teks akan merangsang perhatian hadirin dan hal ini sangat bermanfaat terhadap retensi daya ingat yang lebih baik. Tujuan penulisan ini untuk memberikan pemahaman tentang teknik penyajian suatu presentasi ilmiah secara efektif dengan memanfaatkan penggunaan media elektronik secara tepat.
\end{abstract}

Kata kunci: presentasi ilmiah efektif, media presentasi elektronik.

Koresponden: Elizabeth Mailoa, Bagian Prostodonsia, Fakultas Kedokteran Gigi Universitas Hasanuddin, Jl. Kandea No.5, Makassar, Indonesia. 


\section{PENDAHULUAN}

Pertemuan ilmiah merupakan suatu cara yang paling efektif dalam berkomunikasi, edukasi dan saling berbagi informasi terbaru di antara profesional. Setelah mengikuti berbagai pertemuan maupun kongres ilmiah, biasanya seorang pembicara dalam pertemuan ilmiah menyadari adanya kekurangan dalam penyampaian informasi maupun karya ilmiah baik dalam bentuk penelitian, telaah pustaka maupun suatu studi kasus. ${ }^{1}$

Presentasi ilmiah yang disampaikan secara lisan merupakan teknik yang efektif dan popular di kalangan profesional untuk mentransfer informasi kepada pendengar (audience) dan agar informasi dapat diserap dengan baik serta mudah. Untuk mencapai tujuan ini, maka dibutuhkan kemampuan untuk mempersiapkan materi yang akan dibawakan serta bagaimana cara yang efektif untuk menyampaikan materi agar mencapai sasaran. ${ }^{1,2}$

Kunci keberhasilan seseorang pembicara sewaktu menyampaikan informasi dalam pertemuan ilmiah adalah kemampuan mempersiapkan dan mengorganisasikan materinya semaksimal mungkin dan sekaligus kemampuan menyajikannya di dalam pertemuan ilmiah, agar dapat mempengaruhi dan mengajak pendengar untuk tekun memperhatikan materi yang disajikan pembicara. $^{2}$

Presentasi ilmiah sama halnya dengan kelompok diskusi merupakan suatu aktivitas yang hidup, bukan hanya sekedar penyampaian informasi atau data-data penelitian belaka, namun bertujuan untuk menyatu dengan hadirin, menggunakan bahasa yang dipahami hadirin, memanfaatkan waktu yang disediakan secara efektif serta kemampuan menyajikan presentasi secara menarik. ${ }^{1}$ Komunikasi yang efektif merupakan bagian penting dalam suatu pertemuan ilmiah dengan membangun komunikasi dua arah yaitu dari pembicara sebagai sumber informasi, maupun dari hadirin sebagai penerima informasi. ${ }^{1,2}$

Beberapa studi menunjukkan bahwa sikap seseorang membantu membentuk perilaku yang menentukan suatu tindakan dalam pertemuan ilmiah atau kelompok diskusi, seperti perhatian dan tanggapan terhadap pembicara. Hadirin akan antusias mengikuti presentasi ilmiah dengan topik menarik yang disukainya, dan tidak bersemangat dengan topik yang tidak disukai. Informasi yang diterima hadirin akan berbeda sesuai dengan sikap penerimaan akan topik yang dibahas. Topik yang disukai biasanya lebih mudah dicerna dan daya ingat lebih meningkat dibandingkan dengan topik yang tidak disukai atau tidak menarik. ${ }^{2}$ Oleh karena itu, pembicara dianjurkan untuk mengenal sikap hadirin terhadap materi yang akan dibawakan, apakah yang dihadapi adalah kelompok mahasiswa, kolega seprofesi atau kalangan profesional tidak seprofesi, maupun masyarakat umum, khususnya bagaimana caranya mempresentasikan materi agar dapat mempengaruhi hadirin untuk membangkitkan perhatian sehingga terjadi komunikasi yang efektif. $^{2,3}$

Suatu presentasi yang menarik dengan visualisasi yang jelas merupakan perpaduan antara teks, gambar dan suara yang dapat membangkitkan perhatian dan daya ingat hadirin terhadap materi yang disampaikan pembicara. Fasilitas presentasi dengan multimedia tersebut dimiliki oleh perangkat lunak yang kini banyak dan makin popular digunakan dalam presentasi ilmiah yaitu PowerPoint. ${ }^{2-4}$

Walaupun PowerPoint memiliki banyak keuntungan yang mendukung suatu presentasi ilmiah yang menarik dengan fasilitas yang bervariasi, namun dalam mempersiapkan 
presentasi ilmiah dengan bantuan program presentasi PowerPoint harus juga mengikuti ketentuan pembuatan media presentasi agar lebih efektif dan komunikatif., ${ }^{4,5}$

Dalam makalah ini akan dibahas tentang bagaimana mempersiapkan materi presentasi dengan bantuan PowerPoint serta teknik menggunakan media untuk menyampaikan presenstasi secara efektif dan menarik.

\section{TINJAUAN PUSTAKA}

Dalam suatu pertemuan ilmiah, sering seseorang mendengar dan mengikuti suatu presentasi ilmiah yang pada awalnya menarik, namun beberapa saat kemudian ia merasa sulit untuk mengikuti sampai akhir presentasi. Kebanyakan presentasi menunjukkan suatu hasil yang menarik, namun sering hadirin sulit mengikutinya oleh karena tanpa disadari pembicara membuat kesalahan. Kesalahan yang paling sering terjadi antara lain adalah pembicara tidak menyadari bahwa ia tidak mengajak hadirin untuk ikut terlibat aktif dalam presentasi yang dilakukannya. ${ }^{6}$

Proses awal dalam pembuatan suatu presentasi ilmiah hampir sama dengan proses pembuatan film. Seorang pembicara harus mampu menyatukan beberapa elemen yang berbeda sehingga menjadi suatu cerita yang menarik, dan ini sama dengan kegiatan seorang pembicara dalam mempersiapkan materi presentasinya untuk menghasilkan presentasi yang efektif, komunikatif dan menarik. $^{2}$

Perangkat presentasi yang baik memungkinkan seorang pembicara untuk mengembangkan fasilitas yang ada menjadi suatu gambar hidup yang merupakan perpaduan antara teks, animasi, gambar diam maupun klip video dan suara. ${ }^{2-5}$
Program PowerPoint merupakan suatu perangkat presentasi yang populer dan umum digunakan dalam dunia pendidikan dan bisnis. Apa yang harus diyakini oleh pembicara untuk menghasilkan suatu presentasi yang menarik, berkualitas dan disenangi oleh hadirin? Untuk menghasilkan presentasi seperti itu, maka ada ketentuan dasar presentasi dengan PowerPoint yaitu singkat, jelas dan langsung pada sasarannya. ${ }^{4,5}$

Setiap orang yang berkecimpung di dunia pendidikan paham tentang penggunaan PowerPoint, namun masih banyak keterampilan yang dapat dipelajari untuk membuat suatu penyajian ilmiah menjadi lebih baik. Menghasilkan suatu media presentasi yang menarik dengan bantuan PowerPoint tidak berarti bahwa setiap orang mampu membawakannya dengan baik. $^{7}$

Ada dua hal yang penting dalam penyajian materi dengan bantuan PowerPoint yaitu pada slide pertama dan yang terakhir. Seorang pembicara harus memiliki kemampuan membuka dan menutup pembicaraan saat melakukan presentasi. Jadi sebelum membawakan presentasi, sebaiknya pembicara harus mempersiapkan terlebih dahulu apa yang akan diucapkan saat memulai presentasi dan apa yang ingin dikatakan saat mengakhiri presentasi. ${ }^{6,7}$

Beberapa ahli komunikasi menyarankan agar jangan menutup presentasi ilmiah dengan kalimat “Apa ada pertanyaan?" Kondisi semacam ini akan menyebabkan pembicara menunggu sampai ada tanggapan dan tentu saja ini akan menyita waktu. Kalimat yang baik saat menutup presentasi adalah dengan mengatakan, "Terima kasih atas perhatian anda. Saya akan senang bilamana ada pertanyaan." Pembicara tidak perlu menunggu tanggapan, tetapi segera menyelesaikan presentasi untuk masuk dalam tahap diskusi. ${ }^{5,7}$ 


\section{Persiapan materi presentasi}

Suatu presentasi ilmiah yang baik adalah presentasi yang terdiri dari isi, desain dan cara menyampaikan materi presentasi. Isi adalah informasi aktual yang dipersiapkan untuk dipresentasikan, sedangkan desain merupakan susunan materi presentasi yang aktual berupa slide yang berisi teks, gambar atau grafik dan suara., ${ }^{2,5}$

Banyak faktor yang dapat menghasilkan desain dan tampilan pada slide seperti tampilan latar, komposisi, format dari slide, warna, ukuran dan bentuk huruf, animasi dan lainnya. ${ }^{2}$ PowerPoint memiliki banyak fasilitas yang mendukung desain presentasi, seperti tampilan latar yang bervariasi, fasilitas animasi yang beragam. Namun dalam memilih fasilitas yang akan digunakan dalam presentasi ilmiah jangan sampai membingungkan hadirin. ${ }^{2,4,5}$

Dalam mendesain suatu materi presentasi dengan bantuan PowerPoint, kontinuitas merupakan ketentuan yang harus diperhatikan. Jadi dalam memilih latar, bentuk dan ukuran huruf, serta kombinasi warna latar dan huruf, harus seimbang dan tetap dipertahankan agar tidak mengganggu perhatian hadirin terhadap isi materi yang disampaikan. ${ }^{2}$

\section{Penempatan teks dalam slide}

Komposisi suatu media presentasi hendaknya sederhana, jelas dan mudah terbaca. Penempatan judul menentukan kemudahan bagi hadirin untuk membaca dan menghasilkan tampilan yang menarik. Dianjurkan untuk menempatkan judul teks pada daerah 1/6 dari tepi atas slide, agar masih ada ruang untuk penempatan teks subjudul dan gambar atau grafik. Judul yang ditempatkan pada 1/6 dari tepi bawah slide akan menyebabkan teks menjadi tumpang tindih dan kekurangan tempat untuk menempatkan gambar atau grafik. ${ }^{2}$
Beberapa ahli media menyarankan agar menggunakan bentuk bullet untuk menuliskan teks daripada menggunakan kalimat yang panjang. Jarak yang dianjurkan antar baris tiap bullet adalah 2 spasi. $^{5}$

\section{Pemilihan warna}

Menurut Littrell, $^{8}$ mata manusia dapat menangkap 7.000.000 warna. Beberapa warna diantaranya dapat menyebabkan iritasi pada mata, sakit kepala dan bahkan dapat menyebabkan kerusakan pada penglihatan. Meskipun demikian, ada juga warna yang menyejukkan bila dikombinasikan suatu warna dengan warna yang lainnya.

Warna dapat meningkatkan daya tarik suatu presentasi ilmiah dan menentukan tampilan slide yang menarik. Namun bilamana melakukan kesalahan dalam pemilihan warna untuk suatu presentasi, maka akan menyebabkan kelelahan mata sehingga hadirin tidak akan memberi perhatian yang terfokus pada presentasi. ${ }^{2,3,5}$

Jadi dalam pemilihan warna untuk media presentasi, setiap orang yang akan menyajikan presentasi hendaknya dapat mempelajari teori warna. Warna-warna yang dapat mengganggu penglihatan adalah warna terang dan menyilaukan. Warna ini dapat mengakibatkan rangsangan berlebih pada mata. Warna yang terang dan yang sangat mengganggu penglihatan adalah warna kuning terang, jingga dan merah. Oleh karena itu warna kuning merupakan warna yang mutlak harus dihindari pemakaiannya sebagai latar suatu tampilan slide karena menyebabkan rangsangan berlebihan pada penglihatan manusia. ${ }^{8}$ Di lain pihak, oleh karena warna kuning adalah warna yang terang, maka warna kuning sangat cocok dipilih sebagai warna teks dengan kombinasi warna biru atau hitam sebagai warna latar. 
Dalam mendesain media presentasi, warna untuk judul, teks dan tampilan latar harus dipilih dengan cermat agar presentasi tetap informatif dan komunikatif. Pemilihan warna teks dan tampilan latar haruslah menghasilkan tampilan yang kontras dan mudah dibaca hadirin dengan jelas. Biasanya kombinasi warna teks terang dengan latar gelap merupakan pilihan yang ideal. Misalnya warna teks putih atau kuning dengan latar biru tua atau hitam. $^{3,5}$

Kombinasi warna teks dan warna latar terang menyebabkan tulisan tidak terbaca. Dianjurkan untuk tidak memilih warna latar jingga, kuning atau putih untuk tulisan terang. Misalnya kombinasi latar putih dan teks kuning, atau latar warna jingga dengan teks warna kuning, selain tulisan tidak terbaca, kombinasi warna ini dapat menyebabkan kerusakan penglihatan. ${ }^{8,9}$ Tidak dianjurkan memilih warna teks merah dengan kombinasi latar warna biru atau hitam, atau sebaliknya. Kombinasi latar warna biru dan teks warna merah memberikan hasil yang sangat menyolok dan kombinasi ini juga dapat merusak penglihatan. ${ }^{8,9}$

Pilihan desain latar pada PowerPoint sangat bervariasi, namun sebaiknya dipilih latar yang sederhana, polos dan jangan memilih latar yang terlalu ramai, misalnya latar bunga dengan aneka warna, pemandangan yang penuh dengan panorama, sehingga teks yang dicantumkan menjadi tidak terbaca. ${ }^{2,5}$

Presentasi yang didesain dengan bantuan PowerPoint memang sangat menguntungkan karena fasilitas latar yang dimiliki program ini sangat banyak dan bervariasi. Namun dalam memilih desain latar, diperlukan kecermatan dan pertimbangan yang berhubungan dengan penglihatan manusia. ${ }^{8,9}$

Dalam PowerPoint terdapat pilihan latar warna gradasi dan ada dua pilihan warna gradasi yaitu vertikal dan horisontal. Menurut ahli media, latar dengan warna gradasi vertikal lebih baik daripada warna gradasi horisontal, oleh karena garis warna gradasi vertikal akan menghasilkan teks yang lebih mudah terbaca. ${ }^{8}$

\section{Bentuk dan ukuran huruf}

Dalam komputer ada dua klasifikasi huruf yaitu Serif dan San Serif. Serif memiliki bentuk yang bersudut tajam dan lebih cocok digunakan dalam tulisan buku cetakan, tidak cocok digunakan untuk huruf dalam media presentasi. Contoh huruf Serif adalah Times New Roman. Sedangkan San serif memiliki bentuk garis yang lurus dan tegak, sehingga lebih cocok digunakan untuk huruf dalam media presentasi. Contoh huruf San Serif yaitu Arial, Tahoma, dan Helvetica. ${ }^{2}$

Pemilihan bentuk huruf dalam media presentasi jangan lebih dari tiga, yaitu satu untuk judul, satu untuk teks berikutnya dan satu lagi untuk teks individual dalam satu slide. Jangan menggunakan bentuk teks yang dimiringkan atau menggunakan teks yang terlalu artistik seperti huruf Jerman, oleh karena bentuk huruf ini sangat sulit terbaca. $^{2}$

Ukuran teks yang dipilih juga mempengaruhi desain. Agar hadirin yang berada 10 meter dari layar masih dapat membaca tulisan dalam slide dengan jelas, maka biasanya digunakan ukuran teks minimal 24 point. ${ }^{2,3,5}$ Ukuran bervariasi untuk judul, teks dalam subjudul. Bilamana menggunakan bantuan PowerPoint untuk mendesain materi presentasi, biasanya ukuran sudah standar (default). Untuk judul umumnya 44 point, subjudul 36 point dan teks berikutnya lebih kecil, minimal sampai 24 point, tetapi jangan lebih kecil dari 24 point. $^{2}$

Jangan menggunakan huruf kapital untuk semua slide yang akan dipresentasikan, oleh karena hadirin akan lebih lambat membaca huruf 
kapital dari pada huruf kecil. Sebaiknya menggunakan huruf kapital untuk judul saja, serlanjutnya gunakan huruf kecil saja untuk teks berikutnya dan huruf kapital hanya pada awal kalimat. $^{5}$

Jumlah teks dalam satu slide bervariasi, namun yang direkomendasikan adalah 6 baris satu slide dan tidak lebih dari 6 teks dalam satu baris. Ada yang merekomendasikan delapan baris maupun tujuh baris tiap slide, namun intinya adalah bahwa dalam satu slide jangan terlalu banyak kalimat yang digunakan., 2,,5

\section{Ilustrasi}

Ilustrasi juga merupakan bagian penting dalam presentasi ilmiah. Foto, tabel, gambar, dan clip art merupakan contoh ilustrasi yang dapat digunakan untuk memperjelas informasi dalam suatu presentasi ilmiah. Dalam presentasi ilmiah dengan menggunakan teknologi digital, penempatan foto atau gambar di dalam slide merupakan titik lemah, oleh karena berkaitan dengan kualitas foto atau gambar maupun kualitas peralatan yang digunakan untuk memproyeksikan gambar atau foto dalam slide. ${ }^{2}$

Ada dua cara untuk memasukkan gambar atau foto dalam slide presentasi, yaitu melalui proses scan foto atau langsung menggunakan kamera digital. Prosedur scan dan teknologi kamera digital menghasilkan foto yang berkualitas serta mudah dilakukan croping serta koreksi warna. Hal ini menguntungkan bagi pembicara untuk menampilkan foto dengan komposisi yang bagus. ${ }^{2}$

Foto dapat ditampilkan bersama teks, sehingga hadirin dapat langsung melihat teks dengan foto sekaligus dalam satu slide, sehingga hadirin tidak perlu melihat 2 atau 3 layar yang dapat membingungkan dan mengganggu konsentrasi terhadap informasi yang ditampilkan. $^{2,3}$
Kelemahan dari foto yang berkualitas baik adalah ukuran file menjadi lebih besar dengan akibat memperlambat muatan (loading) komputer, sehingga laju presentasi menjadi lambat dan membuat hadirin bosan dan jenuh. Untuk mengatasi hal ini, maka bilamana suatu presentasi ingin menampilkan foto dari kamera digital, dianjurkan untuk membuat foto dengan format JPEG (Joint Photographic Expert Group). ${ }^{2}$ Foto dengan format JPEG dapat menampilkan gambar dengan kualitas yang baik pada semua proyektor dengan resolusi 1024 X 768 dan kompatibel dengan semua laptop. Foto juga dapat diperkecil dengan menggunakan program mengedit gambar untuk mengurangi ukuran, namun dianjurkan untuk memperkecil ukuran foto tidak lebih dari $10 \% .^{2}$

Tampilan foto pada slide dalam suatu presentasi sangat membantu pemahaman suatu topik yang dibicarakan, dan foto akan lebih jelas bilamana ditambahkan garis pigura. Pigura dapat dibuat dengan fasilitas garis yang dimiliki setiap komputer dan dianjurkan ketebalan tepi garis sebesat 2,25 point menggunakan warna yang kontras dengan warna tampilan latar. Umumnya warna tampilan latar biru atau hitam, maka sebaiknya dipilih warna garis piguranya putih atau kuning.

Grafik sebagai salah satu kategori ilustrasi biasanya ditampilkan dalam suatu presentasi ilmiah untuk menjelaskan konsep yang sulit dituangkan dalam bentuk teks maupun bentuk foto atau gambar. Ada beberapa jenis grafik, antara lain grafik batang, grafik pie dan grafik garis. ${ }^{4}$ Ketentuan dalam menampilkan grafik baik batang, pie dan garis adalah untuk grafik batang jangan menumpuk dalam satu grafik. Untuk grafik pie dianjurkan tiap potongan diwarnai dan jangan dibuat potongan berupa bagian yang terpisah. ${ }^{3,4}$ 


\section{Tampilan slide}

Untuk tampilan slide dalam layar, saat mulai mendesain media presentasi, dianjurkan untuk memilih format landscape (horisontal) daripada format portrait (vertikal), karena format landscape lebih menguntungkan untuk menempatkan teks dan gambar sesuai ketentuan karena ruangnya lebih luas, sedangkan format portrait menyebabkan ruang menyempit sehingga tidak dapat memenuhi ukuran teks dan penempatan gambar dengan leluasa. ${ }^{3}$ Denisson $\mathrm{dkk}^{3}$ menganjurkan untuk memilih posisi landscape sebagai tampilan slide di layar, sekalipun tidak ada larangan untuk menggunakan posisi portrait.

\section{Suara dan animasi}

PowerPoint juga memiliki fasilitas untuk membuat animasi sekaligus dengan suara (sound). Bilamana digunakan secara benar, maka suara dapat membantu menarik perhatian hadirin, namun bila suara terlalu banyak digunakan, maka hal ini juga akan mengganggu konsentrasi hadirin. Jadi dianjurkan untuk tidak terlalu sering menggunakan suara, suara hanya digunakan pada saat membutuhkan perhatian. ${ }^{2}$

Animasi dapat digunakan untuk membuat perhatian hadirin terfokus pada topik yang perlu penekanan tertentu. Animasi dianjurkan hanya dua bentuk, yaitu dalam satu slide (custom animation) dan dari satu slide ke slide yang berikutnya (slide transition). Terlalu banyak menampilkan animasi, selain memperlambat tempo presentasi juga sangat mengganggu konsentrasi hadirin. ${ }^{2,3,5}$

Fasilitas transisi dari satu slide ke slide berikutnya yang dimiliki PowerPoint juga bervariasi dan banyak pilihannya, namun transisi yang terlalu aktif akan menyebabkan hadirin menjadi bosan dan bahkan dapat menyebabkan kelelahan pada mata. $^{2}$

\section{Teknik penyajian materi}

Seorang ilmuwan bisa merupakan satusatunya orang yang dapat mengatakan sesuatu saat ini, namun bisa saja merupakan orang yang tidak tahu apa yang harus dikatakan. ${ }^{9}$

Dalam penyajian materi presentasi setiap orang pasti akan merasakan demam panggung atau gugup menghadapi hadirin tak terkecuali seorang profesional sekalipun. Gugup atau demam panggung merupakan kondisi wajar untuk setiap orang, terutama bagi yang baru pertama kali menghadapi hadirin. ${ }^{7,9}$ Perasaan gugup ini timbul karena seseorang merasa harus tampil sesempurna mungkin, mencoba melakukan presentasi sebaik mungkin dalam waktu yang begitu singkat, tidak percaya diri, atau karena takut mendapat pertanyaan yang mungkin tidak bisa dijawab. ${ }^{9}$

Beberapa ahli komunikasi ${ }^{9-11}$ menganjurkan lima faktor penting untuk mengatasi masalah demam panggung seorang yang akan menyajikan presentasi ilmiah. Pertama, faktor percaya diri yang penting oleh karena seseorang dengan percaya diri yang tinggi akan lebih siap menghadapi perasaan gugup. Faktor kedua adalah penguasaan materi, karena materi yang dibawakan adalah materi yang harus dikuasai. Hanya pembicara yang mengetahui semua masalah yang berhubungan dengan topik yang akan dibawakan. Jadi, dengan menguasai materi, pembicara merasa lebih siap, oleh karena materi yang dibawakan belum tentu dipahami oleh semua hadirin. Selanjutnya faktor pengenalan karakter hadirin. Karakter hadirin perlu dipahami sehingga pembicara mudah memilih topik yang disenangi hadirin, maupun memenuhi kebutuhan hadirin yang mengikuti presentasi yang disampaikan. Keempat adalah komunikasi yang baik, karena menjalin komunikasi yang baik antara pembicara dengan hadirin yaitu cara menyampaikan presentasi dengan menggunakan bahasa yang 
dikenal hadirin, menyajikan hal-hal yang menarik perhatian hadirin sesuai dengan karakteristiknya. Berbicara dengan hadirin yang terdiri dari mahasiswa atau orang awam akan sangat berbeda bila menghadapi kalangan profesional. Yang terakhir adalah suara yang mantap. Membawakan presentasi hendaknya menggunakan suara yang bervariasi, sehingga tidak terdengar monoton. Suara yang kecil dan datar dengan artikulasi yang tidak jelas membuat suasana sangat membosankan dan tidak dapat dipungkiri membuat beberapa hadirin akan tertidur.

Ada beberapa hal yang perlu diperhatikan dalam menilai tampilan seorang pembicara saat menyajikan presentasi ilmiah. Pertama, berbicara dengan suara yang jelas, dengan artikulasi yang tepat, dan tidak terlalu cepat atau terlalu lambat. Bila berbicara terlalu cepat, hadirin akan sulit mengikuti topik yang sedang dibicarakan, sebaliknya berbicara terlalu lambat membuat hadirin merasa bosan dan mengantuk. Artikulasi yang tidak jelas menyebabkan hadirin tidak mengerti ucapan apa yang sedang disampaikan pembicara. ${ }^{8-10}$ Kedua, tetap melakukan kontak mata dengan hadirin dan pertahankan selama mungkin untuk melihat respon hadirin terhadap apa yang sedang dibicarakan. Melakukan presentasi dengan menghadap hadirin akan membangun jalinan komunikasi yang efektif dengan hadirin. ${ }^{8,9,11}$ Ketiga, jangan terlalu sering membaca teks di layar atau pada catatan di atas meja pembicara, oleh karena tampaknya pembicara tidak sedang berbicara dengan hadirin, dan kesannya pembicara tidak terlalu menguasai materi yang dibawakan. ${ }^{10,11}$ Keempat, usahakan untuk membuat materi presentasi sendiri tanpa bantuan orang lain, sebab dengan menguasai materi yang akan dibawakan, maka alur pembicaraan menjadi lebih lancar, sebab pembicara sudah mengetahui apa yang akan dibicarakan setiap lembar slide yang akan ditampilkan. Namun bilamana presentasi terpaksa harus dibuatkan oleh orang lain, maka usahakan untuk mempelajari materi sebelum tampil di depan hadirin. Dengan demikian pembicara sudah mengetahui isi topik slide berikutnya, apa yang harus dibicarakan, dan bagaimana mengatur alur pembicaraan dari slide pertama sampai slide yang terakhir. ${ }^{11,12}$ Kelima, jangan menunjuk langsung ke layar menggunakan jari atau alat penunjuk, seperti pulpen yang sedang dipegang, melainkan gunakan laser pointer, sehingga hadirin lebih terfokus pada topik yang sedang dibicarakan. ${ }^{11,12}$ Keenam, tampilkan slide demi slide secara teratur, sesuai topik yang sedang dibawakan sehingga hadirin dapat mengikuti materi presentasi secara runtut dan sistematik. ${ }^{9}$ Ketujuh, untuk menutupi rasa demam panggung saat melakukan presentasi, biasanya pembicara cenderung membuat gerakan yang berlebihan, misalnya memasuk-keluarkan tangan dari kantong celana, memainkan pulpen yang sedang dipegang atau berjalan mondar mandir di depan hadirin. Presentasi sambil bergerak mendekati hadirin memang efektif untuk membangun komunikasi, namun jangan terlalu aktif. ${ }^{9-11}$ Kedelapan, sekalisekali menyisipkan humor yang sehat, namun jangan menjadikan humor sebagai topik utama dalam presentasi. Dengan kata lain jangan berlebihan menyampaikan humor. Dianjurkan untuk menyajikan pengalaman lucu dan mungkin agak aneh dari diri sendiri yang bisa membangkitkan suasana menjadi lebih santai. Jangan menceritakan pengalaman lucu orang lain yang mungkin tidak mau menjadi bahan tertawaan, apalagi bila menyebutkan namanya. ${ }^{9-11}$ Kesembilan, dalam menyiapkan materi presentasi perlu mempertimbangkan waktu yang disediakan, sehingga saat melakukan presentasi pembicara tidak terlalu cepat mengakhiri presentasi atau 
terkesan terburu-buru agar topik presentasi dapat disajikan semuanya, tanpa menghilangkan beberapa informasi bagi hadirin. ${ }^{2,8,9}$

\section{PEMBAHASAN}

Dalam menyajikan presentasi ilmiah, seorang pembicara perlu memperhatikan banyak faktor agar penyampaian materi tidak sekedar berupa pemindahan informasi belaka, atau hanya terjadi pertukaran ilmu pengetahuan yang aktual, melainkan juga bagaimana bersikap menjadi seorang komunikator yang memiliki sikap yang dapat memikat hati dan perhatian orang yang diajak berkomunikasi. ${ }^{3}$

Merancang suatu presentasi ilmiah tidaklah terlalu sukar karena mudah dipelajari, namun bagaimana menyajikannya secara efektif, menuntut kemampuan retorika, bakat dan minat seorang pembicara untuk dapat mengintegrasikan desain dan isi materi menjadi suatu kegiatan presentasi ilmiah yang menarik..$^{7-9}$

Prosedur persiapan presentasi ilmiah diawali dengan beberapa pertanyaan seperti "materi apa yang mau disampaikan, siapa hadirin yang akan dihadapi, apakah materi ini cukup aktual atau sudah terlalu sering dibawakan dalam forum ilmiah, apakah bermanfaat bagi hadirin setelah mengikuti presentasi ilmiah?" Berdasarkan pertanyaan tersebut pembicara bisa mengumpulkan jawaban yang dapat menjadi bekal untuk mempersiapkan suatu materi presentasi yang efektif., ${ }^{2,8}$

Mengenal hadirin yang dihadapi akan membantu pembicara dalam mempersiapkan materi yang dapat menarik perhatian, dan mengubah sikap hadirin yang belum memiliki pengetahuan tentang materi yang dibawakan menjadi suatu materi yang bermanfaat.

Berdasarkan studi yang dilakukan Flemin dan Levi yang dikutip Marchack, ${ }^{1}$ sikap dapat membantu membentuk perilaku seseorang yang menentukan aksi, misalnya perubahan perhatian dan penerimaan akan suatu materi. Jadi bila pembicara mengenal karakteristik hadirin yang akan dihadapi, maka dengan mudah ia akan mempersiapkan, mendesain dan menyajikan materi presentasi yang dapat merangsang perhatian dan minat hadirin. ${ }^{2}$

Dalam mendesain materi presentasi dengan bantuan program PowerPoint, semua elemen yang mendukung presentasi yang merupakan perpaduan teks, animasi dan suara, serta pemilihan komposisi warna turut berpengaruh terhadap efektivitas suatu presentasi ilmiah. Desain teks dalam slide yang menggunakan terlalu banyak efek italic atau dimiringkan, membuat hadirin sukar untuk membaca dengan cepat. Hasil sebuah penelitian yang dilakukan untuk menilai daya tangkap dan kualitas retensi daya ingat mahasiswa terhadap slide dengan teks yang berbeda, yaitu Arial dan Times New Roman, menyimpulkan bahwa bentuk huruf sederhana seperti Arial membantu meningkatkan daya tangkap dan retensi daya ingat mahasiswa terhadap materi yang disajikan. $^{2}$

Suatu presentasi yang baik merupakan perpaduan antara isi, desain dan cara menyampaikan materi. Cara menyampaikan materi akan sangat menarik dan efektif bilamana dilakukan dengan mempertimbangkan suara, gerakan badan dan penampilan saat menyajikan materi.

Menyajikan materi bukan suatu hal yang mudah, sehingga membutuhkan latihan yang cukup, oleh karena setiap orang mengalami demam panggung, takut berbicara di depan orang banyak. Beberapa penelitian menunjukkan bahwa ketakutan yang paling besar dalam kehidupan seseorang adalah berbicara di depan umum. Beberapa studi bahkan menemukan bahwa 
seseorang lebih takut berbicara di depan umum daripada digigit ular berbisa. ${ }^{11,12}$

\section{SIMPULAN}

Teknologi digital yang berkembang saat ini dapat meningkatkan nilai presentasi yang klasik menjadi suatu pengalaman belajar yang sangat berharga dan menjadi sumber penyajian yang menarik dan menyenangkan bagi pembicara maupun hadirin. PowerPoint sebagai salah satu alat bantu presentasi dengan teknologi digital sudah populer di kalangan profesional baik di bidang pendidikan maupun kalangan bisnis, oleh karena memiliki fasilitas multimedia yang dapat memadukan teks, animasi dan suara. Fasilitas inilah yang merupakan sumbangsih terbesar untuk menghasilkan presentasi yang menarik.

Presentasi ilmiah dengan bantuan media elektronik mempunyai banyak keuntungan, terutama dalam mendesain presentasi yang menarik, efektif dan komunikatif. Akan tetapi bila tidak didesain dengan cermat dan sesuai ketentuan maka akan terjadi kegagalan dalam membangun komunikasi yang efektif antara pembicara dengan hadirin.

Dalam mempersiapkan desain materi presentasi dengan bantuan PowerPoint, hendaknya memperhatikan kesederhaan dalam desain, penyajian teks singkat dan berupa kata kunci, pilihan warna teks dan warna latar yang efektif, dan memilih posisi slide yang sesuai.

Saat menyajikan materi presentasi, pembicara harus berusaha untuk berdialog dengan hadirin dan bukan berbicara dengan dirinya sendiri, sehingga dalam penyajian presentasi hendaknya tetap menjaga kontak mata dan berhadapan dengan hadirin selama menyajikan materinya karena merupakan teknik yang sangat efektif dalam menjalin komunikasi.

\section{DAFTAR PUSTAKA}

1. Hoffman M, Mittelman M. Presentations at professional meetings: notes, suggestions and tips for speakers. Eur J Intern Med 2004; 15: 358-63.

2. Marchack BC. Guidelines for digital scientific presentations. J Prosthet Dent 2002;88: 64953.

3. Denisson W, Jones A, Saxby T. The art of science communication. Available from http://www.ian.umces.edu/using

PowerPointeffectively.pdf. Diakses 23 Mei 2007.

4. Willies B. Using PowerPoint effectively. Available from http://www.worsleyschool.net/science/

PowerPoint/page.html. Diakses 9 Maret 2006.

5. Lengel J. Teaching with technology-how to make a slide show with PowerPoint. Available from

http://www.powertolearn.com//teaching_with technology/how to make a slide show wit h_PowerPoint.html. diakses 12 Juli 2006.

6. Harrison J. Planning a scientific presentation. Available from http://www.tag.ubc.ca/scientificpresentation/planning.pdf. Diakses 25 Januari 2008.

7. Niemantsverdriet JW. How to give a successful oral presentation. Available from http://www.efcats.org/Efcatstalkingyips.pdf. Diakses 25 Februari 2007.

8. Littrell FR. Presentation techniques: Effectiveness of PowerPoint presentations in lectures. Available from http://presentationsoft.about.com/lose_audienc e.htm. Diakses 25 Januari 2008.

9. Miller L, Weaver A, Johnson C. Giving a good scientific presentation. Available from http://www.asp.org/education/howto_onPoster s.html. Diakses 22 November 2007.

10. Freemann R. How to give an affective scientific presentation. Availale from http://www.

kumc.edu/SAH/OTEd/jradel/generalpresentati on skills-note.pdf. Diakses 22 November 2007. 
11. Raddel J. Guide for oral presentation techniques. Available from http://www.dcc2.bumc.bu.edu/ prdu/Session_Guides/oral_presentation_techni ques.htm. Diakses 22 November 2007.
12. Callen JD. Preparation of effective scientific talks. Available from http://www.web.cba.neu.edu/ ewertheim/skill s/oral.htm. Diakses 18 Desember 2007. 